\title{
Amphibians and reptiles of the Dominican Republic: species of special concern
}

\author{
Robert Powell, José A. Ottenwalder, Sixto J. Incháustegui, Robert W. Henderson and Richard E. Glor
}

\begin{abstract}
The Dominican Republic faces multiple threats to biodiversity. A list of native species of amphibians and reptiles (excluding sea turtles) is presented. Some may have become extinct recently, substantial populations of others have been extirpated, some have greatly reduced numbers, and others appear to be rare or have restricted ranges. Most of the 13 taxa listed are relatively large, vulnerable to human exploitation or introduced predators, and/or have limited distributions and specific habitat requirements. To be listed, evidence must exist that: (1) populations are dwindling, (2) the range is shrinking, or (3) a species must be vulnerable to exploitation and historically rare. Two iguanas (Cyclura cornuta, C. ricordii), two turtles (Trachemys decorata, $T$. stejnegeri vicina), and one crocodilian (Crocodylus acutus) have been exploited extensively and have long been recognized as threatened
\end{abstract}

or endangered. The ranges of Cyclura ricordii and $T$. decorata are very localized and the previously widespread ranges of the others have shrunk or become fragmented. A toad (Bufo fluviaticus), a large galliwasp (Celestus anelpistus), and a snake (Alsophis melanichnus) have not been collected recently. Only a few specimens of another galliwasp (C. carraui) and a dwarf gecko (Sphaerodactylus cochranae) have been taken recently. In addition, extensive portions of the habitats of these species have been severely altered. Three other snakes (Alsophis anomalus, Ialtris agyrtes, I. dorsalis) are rare and may never have been common. Their size and habits render them vulnerable to predation by the introduced mongoose and to decimation by humans who fear and dislike them.

Keywords Amphibians, conservation, Dominican Republic, threatened species, reptiles.
The Dominican Republic, with a total area of $49,730 \mathrm{sq} \mathrm{km}$, occupies about two-thirds of the island of Hispaniola, which it shares with the Republic of Haiti. Like many other island nations in the Caribbean Basin (Harcourt et al., 1996), the Dominican Republic faces the multiple threats to biodiversity posed by a growing population (with attendant urban sprawl and the need for increased agricultural productivity) and economic development (a considerable component of which is in the form of tourism). The human population of the

Robert Powell (corresponding author) Department of Natural Sciences, Avila College, 11901 Wornall Road, Kansas City, MO 64145, USA. Tel: + 1816942 8400; fax: + 1816942 3362; e-mail: powellımail.avila.edu

José A. Ottenwalder Biodiversity Strategy and Environmental Policy Projects Coordination Unit, National Planning Office (ONAPLAN) and United Nations Development Programme, P.O. Box 1424, Santo Domingo, República Dominicana.

Sixto J. Incháustegui Grupo Jaragua, El Vergel 33, El Vergel, Santo Domingo, República Dominicana.

Robert W. Henderson Section of Vertebrate Zoology, Milwaukee Public Museum, Milwaukee, WI 53233, USA.

Richard E. Glor Department of Biology, Washington University, St Louis, MO 63130, USA.

Received 27 July 1999. Accepted 30 November 1999
Dominican Republic stood at 7.8 million in mid-1994 (Harcoürt \& Ottenwalder, 1996), and population density has increased from $48 / \mathrm{sq} \mathrm{km}$ in 1950 to a projected $177 / \mathrm{sq} \mathrm{km}$ in 2000 and 203/sq km in 2010 (MacDonald, 1992). Although annual growth rates appear to be slowing (an estimated 2.2 percent in mid-1994 and 1.9 per cent from $1990-2000$ to a projected 1.4 per cent from 2000-2010), the pressure on land availability and productivity continue to rise.

The concomitant assault on the natural habitats of many native species has had mixed effects. Whereas some species (e.g., the lizard, Anolis cybotes) thrive in altered situations, the very existence of many others is threatened (Lenart et al., 1997; Henderson \& Powell, 1999; Glor, 1999; Glor et al., in review). The purpose of this article is to focus attention on those native Dominican species of amphibians and reptiles (excluding sea turtles) that may have become extinct recently, have experienced substantial extirpations of populations, have greatly reduced populations that are particularly sensitive to human disturbance, or appear to be rare or have restricted ranges and about which knowledge is simply inadequate to draw definitive conclusions. Schubert (1993) noted that 'currently available data' precluded accurate estimates of the number of species lost to human activities. That situation has not improved substantially and, as always, the most critical missing link is accurate and timely information. 
Because conservation issues, of necessity, often are addressed at the national rather than biogeographic level, we treat the Dominican Republic as an independent entity, although it is, in reality, only one part of the single biogeographic unit of Hispaniola. The Dominican Republic is an ideal choice for an overview such as this. Unlike, for example, Haiti, with only about 1 per cent of its historically forested areas (Harcourt \& Ottenwalder, 1996; Hedges, 1996, 1999; Henderson \& Powell, 1999), or Antigua, nearly the entire island of which was converted to a monoculture of sugar cane during colonial times (Jenkins \& Harcourt, 1996), the Dominican Republic still supports some extensive, albeit scattered, patches of natural habitat (Tolentino \& Peña, 1998), approximately 16.5 per cent of which are afforded some protection as part of 40 distinct entities, primarily national parks (Hoppe, 1989; Valdez Sierra \& Mateo Féliz, 1992, Ottenwalder, 2000c). Although the historically widespread lowland forests have been destroyed (Powell \& Henderson, 1996; Hedges, 1999), most other forest types are declining at a relatively slow pace and many xeric areas are nearly pristine. However, the extent of all forests and woodlands had decreased from $14,280 \mathrm{sq} \mathrm{km}$ in 1980 to $10,770 \mathrm{sq} \mathrm{km}$ by 1990 , an annual reduction of 2.5 per cent (World Resources Institute, 1994). A more recent and slightly more optimistic estimate of wooded area was $13,266 \mathrm{sq} \mathrm{km}$ and of the annual deforestation rate $246-264 \mathrm{sq} \mathrm{km}$ (Ottenwalder, 2000c). The differences are less due to optimism than the means of assessing disturbed forests, more of which were included in the latter estimate. Nevertheless, the existence of many species in developing island nations is in peril. Compared with other Antillean islands, however, the increasing awareness by Dominicans of environmental concerns suggests that reasonable hope exists for many Dominican species and their habitats. However, the picture is not all bright, as the list below will testify.

The list below is not intended to be a comprehensive, final authority on threatened or potentially threatened Dominican amphibians and reptiles. Instead, its purpose is to draw attention to those species that we consider to be most vulnerable and that are the utmost priorities for conservation action (Table 1). As more information comes to light or as conditions change, some of the listed species may benefit, whereas other taxa not listed may become imperiled. Previous listings and appraisals have included very common species (Aquino, 1983) or listed non-Dominican taxa. The latest IUCN lists (Groombridge, 1993; IUCN, 1996), for example, include as 'threatened' one amphibian and ten species of reptiles (including four sea turtles) from the Dominican Republic, the highest number for any Neotropical nation except México. In our list of one amphibian (a different species) and 12 species of reptiles (excluding sea turtles), several species represent proposed additions to the threatened list for the country. In addition, the status of formerly listed species is discussed and reviewed.

Table 1 Threatened and 'near-threatened' species of amphibians and reptiles from the Dominican Republic, as listed by Aquino (1983), the IUCN Red List (Groombridge, 1993; IUCN, 1996), and this paper as 'threatened' (T), 'lower risk' (LR), or 'data deficient' (DD)

\begin{tabular}{|c|c|c|c|}
\hline Species & Aquino (1983) & IUCN (1996) & This paper \\
\hline \multicolumn{4}{|l|}{ Amphibia: Anura } \\
\hline Bufo fluviaticus & - & - & $\mathrm{T}$ (critically endangered) \\
\hline Hyla vasta & - & $\mathrm{T}$ (vulnerable) & - \\
\hline \multicolumn{4}{|l|}{ Reptilia: Testudines } \\
\hline Trachemys decorata & $\mathrm{x}$ & $\mathrm{T}$ (vulnerable) & T (vulnerable) \\
\hline Trachemys stejnegeri vicina & $x$ & LR & $\mathrm{LR}$ \\
\hline \multicolumn{4}{|l|}{ Reptilia: Squamata } \\
\hline Celestus anelpistus & $x$ & $\mathrm{~T}$ (critically endangered) & $\mathrm{T}$ (critically endangered) \\
\hline Celestus carraui & $x$ & $\mathrm{~T}$ (endangered) & $\mathrm{T}$ (endangered) \\
\hline Sphaerodactlylus cochranae & - & - & $\mathrm{T}$ (endangered) \\
\hline Cyclura cornuta & $\mathrm{X}$ & $\mathrm{T}$ (vulnerable) & $\mathrm{T}$ (vulnerable) \\
\hline Cyclura ricordii & $\mathrm{x}$ & $\mathrm{T}$ (critically endangered) & $\mathrm{T}$ (critically endangered) \\
\hline Alsophis anomalus & - & - & DD \\
\hline Alsophis melanichnus & - & - & $\mathrm{T}$ (critically endangered) \\
\hline Ialtris agyrtes & - & - & $\mathrm{T}$ (endangered) \\
\hline Ialtris dorsalis & - & - & $\mathrm{DD}$ \\
\hline \multicolumn{4}{|l|}{ Reptila: Crocodylia } \\
\hline Crocodylus acutus & $x$ & $\mathrm{~T}$ (vulnerable) & $\mathrm{T}$ (vulnerable) \\
\hline
\end{tabular}

Because these assignments are those of the Red List, their use for taxa listed by Aquino (1983) and this paper is based on our best efforts to apply the relevant IUCN criteria. 
In addition to listed taxa, a number of species with limited distributions (e.g. the anurans Bufo fractus and Eleutherodactylus cochranae, and the gekkonid lizard Sphaerodactylus perissodactylius) are locally abundant, but their very restricted ranges render them exceedingly vulnerable to stochastic events, of either natural or human origin. Other species (e.g. many montane frogs, the lizard Anolis barbouri, the giant anoles, $A$. baleatus, $A$. barahonae and $A$. ricordii) have highly specific habitat requirements that render them particularly vulnerable to ongoing deforestation. Still others (e.g. the anuran Hyla vasta, which was included in recent IUCN lists, and the lizards Anolis whitemani and Mabuya lineolata) have fragmented ranges, portions of which are sparsely populated. We have chosen to exclude these examples, and many other species in similar situations, not because their populations are secure, but because any substantial concern is probably premature and might distract attention from the plights of other, currently more vulnerable species. Certainly, considering the unpredictable effects on natural habitats by human actions, one or more of these species could become endangered suddenly and in the very near future.

Snakes in the family Boidae are granted protection under the Convention on International Trade in Endangered Species (CITES); however, all three Dominican species (Epicrates fordii, E. gracilis, E. striatus) appear to be sustaining viable populations, sometimes even in heavily disturbed areas. These species do deserve protected status because of their vulnerability to exploitation by the pet trade and, to a lesser degree, their dependence on threatened habitats. However, at least in the Dominican Republic, they seem to be less vulnerable to extirpation or extinction than the species we have listed.

In contrast, small, secretive, burrowing squamates in the families Amphisbaenidae, Leptotyphlopidae and Typhlopidae are often locally abundant in areas where they may be difficult to find much of the time and under any conditions that are less than ideal. Consequently, when we fail to find them, we merely assume that we were searching in the wrong place or at the wrong time. Some forms may be quite rare, but we simply lack the information to make those determinations.

Complicating these issues even further is the possibility that some populations currently recognized as subspecies (Powell, 1993; Williams, 1999) and isolated populations not recognized even at the subspecific level may represent unique gene pools within widespread species complexes and warrant recognition as full species. Without continuing efforts to survey and analyse especially the isolated populations, species may decline or even disappear without an awareness of their existence.
In general, illegal international trade is not a major problem in the Dominican Republic today. The situation has been improving gradually since the late 1980s with the ratification of CITES and with reasonably effective controls of wildlife exports in place by 1995 . However, substantial threats are posed by subsistence consumption for food of species with relatively large body size (turtles, iguanas, some snakes and the crocodile) and other cash income uses of whole animals or parts (oil, shells and skins) in traditional culture (i.e. medicinal, aphrodisiac or religious applications). Ongoing habitat degradation, however, is beyond any doubt the main threat to amphibians and reptiles throughout the country.

Consequently, the list of species presented below probably represents but a fraction of the taxa that could be listed. We have chosen to limit the list to those forms for which currently available information points to the reality or very high probability of recent or imminent extinction-and, in the latter case, species for which current protective measures must be maintained or effective remedial efforts be initiated and enforced in the near future. Species are listed in the order in which they appeared in the most recent West Indian checklist (Powell et al., 1996). Familial designations are given to facilitate comparisons, although inclusion of one form should not be interpreted to mean that the same or even similar conditions apply to all confamilial taxa. In addition, the inclusion of a species in this list should not be construed as justification for an immediate imposition of any protected status. Where appropriate, existing designations are noted and, in instances for which we believe immediate designations are warranted, we have explicitly stated as much. However, in all other instances, what is both justified and necessary is for international and Dominican agencies to encourage, by all means available, surveys of habitats occupied by these species, detailed studies of their natural histories, and the development of status reports that may (or may not) lead to protected status.

Most of the forms listed below are relatively large, particularly vulnerable to human exploitation or introduced predators, and/or have limited distributions and very specific habitat requirements. To be listed, evidence must exist that population numbers are dwindling or the range is shrinking as a consequence of human activities. Alternately, a species must be vulnerable to exploitation (e.g. susceptible to alien predators) and historically rare, defined herein as not having been collected frequently in the past century, and especially in the past 35 years, when intensive collecting efforts on Hispaniola were initiated by the late Albert Schwartz (Powell \& Henderson, 1996). 
The two iguanas (Cyclura cornuta and C. ricordii), the two turtles (Trachemys decorata and $T$. stejnegeri vicina), and the one crocodilian (Crocodylus acutus) have been recognized as threatened or endangered for some time (Aquino, 1983). All have been exploited extensively for food or hides and often subjected to indiscriminate killing. Population numbers have declined. The ranges of Cyclura ricordii and Trachemys decorata are very localized and the previously widespread ranges of the other species have shrunk or become fragmented. Possibly because of the heightened awareness of their plight and inclusion in protected areas, however, at least several local populations of Cyclura cornuta have recovered to some extent and a few may approach pre-Columbian numbers. Threats to the Crocodylus acutus population in Lago Enriquillo have been mitigated in the past few years, although that trend must continue for some time to be effective in a species that matures slowly and occupies a low-productivity environment (Incháustegui et al., 1978). In general, all of these species have been dramatically and adversely affected by human activities, some still are, and all deserve the protection they receive.

The toad (Bufo fluviaticus), one of the large galliwasps (Celestus anelpistus) and one of the racers (Alsophis melanichnus) have not been collected recently, the latter not since 1910. Only a few specimens of the other galliwasp (C. carraui) and the dwarf gecko (Sphaerodactylus cochranae) have been taken since their descriptions in 1985 and 1946, respectively. In addition, extensive portions of the known habitats of all of these species have been severely altered, possibly precluding the recovery of populations that may not even exist today-especially because we know so little about these species that we cannot begin to assess the degree to which they are specialized for particular environmental conditions.

Justifying the inclusion of the remaining snakes (Alsophis anomalus, Ialtris agyrtes and $I$. dorsalis) is more problematic, especially because we have chosen not to include the three Dominican species of Epicrates. However, in spite of the fact that some satellite island populations ( $A$. anomalus on Isla Beata, and $A$. anomalus and $I$. dorsalis on Île de la Tortue in Haiti), may be relatively healthy, all three species are rare in comparison with Epicrates, with many fewer specimens represented in museum collections. In addition, the fact that these snakes have been found in widely available habitats speaks to the likelihood that they may never have been common. Further, their size and habits render them vulnerable to predation by the introduced mongoose Herpestes javanicus and to decimation by humans who fear and dislike them. Finally, what we know about their habitat requirements is anecdotal and, perhaps because of their rarity, no focused studies have addressed any aspects of their natural history. Consequently, we have chosen to include them here as much to focus attention on their plight as to reinforce any acknowledged awareness of their potentially threatened state.

Surprisingly, in light of current concerns regarding declining amphibian populations (e.g. Green, 1997), 13 of the 14 species on our list are reptiles. Three factors may be implicated in the paucity of amphibians listed: (1) field studies in the Dominican Republic have focused most frequently on diurnal reptiles, often to the detriment of work on frogs (Powell \& Henderson, 1996); (2) for the most part, frogs are small compared with most listed species (Sphaerodactylus cochranae is a notable exception) and consequently less conspicuous by either their presence or absence; and (3) most frogs may still be quite abundant, at least in the relatively small remaining patches of suitable habitat (Hedges, 1999). However, the greatest diversity of amphibians is associated with the moist upland forests. Consequently, the number of amphibian species in immediate danger of extinction has the potential to grow rapidly as these habitats continue to disappear.

\section{Bufo fluviaticus (Bufonidae)}

The endemic toad Bufo Fluviaticus (formerly in the genus Peltophryne) is considerably smaller than all but one other species included in this list. Its range is extremely localized, with specimens known only from two sites, the type locality near Los Quemados and from near Santiago Rodríguez, both in Santiago Rodríguez Province (Schwartz \& Henderson, 1991). The very limited amount of information available on natural history was presented by Schwartz (1972). Pregill (1981) suggested that the mesic sites where specimens have been taken represented relict enclaves of historically more widespread mesic conditions in what is now a generally xeric, acacia- and cactus-dominated landscape. No specimens have been taken since the 1970 s (Powell \& Pregill, 1991; Hedges, 1999). A visit in the early 1990 s to the type locality under conditions unsuitable for toad activity revealed considerable habitat alteration in the form of a gravel mine along the stream near where the holotype was collected. Although these localities are in areas not heavily visited by herpetologists, the absence of recent records and the admittedly anecdotal evaluation of the habitat would suggest at best a rare form and at worst extinction. Efforts to survey appropriate areas in and near the known collection sites under conditions conducive to toad activity should be encouraged. Until then, inadequate information precludes any substantive evaluation of the spe- 
cies's status. For a summary of the pertinent literature, see Powell \& Pregill (1991).

\section{Trachemys decorata (Emydidae)}

The endemic slider Trachemys decarata also has a restricted distribution; specimens are known only from lakes (Lago de Fondo [Etang Saumatre], Lago Enriquillo, Laguna del Rincón) in the Valle de Neiba (Schwartz \& Henderson, 1991) and in wetlands of Jaragua National Park. What is known about the natural history was presented by Incháustegui (1972-73, 1975). All known populations have declined substantially in recent years. Consumption as food by local inhabitants, as a gourmet dish for city dwellers, and various uses in traditional medicine have resulted in a high price and demand for turtles. Although densities in most areas have dropped well below levels capable of sustaining economically justified collection efforts, individuals continue to be taken opportunistically, showing up frequently in local markets (Schubert, 1993) and even occasionally in markets as far as Santo Domingo. Further complicating the potential recovery of populations may be the fact that a very large percentage of turtles observed recently are males, presumably the result of preferential exploitation of the larger females by poachers and the fact that most animals are taken during the breeding season, when females come to shore for egg deposition. Although some populations of these turtles are afforded some protection by the inclusion of their habitat in national parks, efforts to educate local fishermen must accompany systematic surveys to establish accurately current population sizes. Along with ongoing conservation and public education, concerted efforts at captive propagation and release (Ottenwalder, 1994a,b) may eventually be necessary for recovery to self-sustaining levels. For a summary of the pertinent literature, see Bickham (1980).

Because of its conservation status and restricted range in the wild, Trachemys decorata was selected for conservation action by the AAZPA/Chelonian Advisory Group (CAG) and a captive breeding programme was recommended during the 1990-91 CAG working meeting (Ottenwalder, 1994a). The programme was implemented in 1991 with participation by 10 zoos, including the Parque Zoológico Nacional (ZOODOM) in Santo Domingo. Initial efforts at ZOODOM resulted in high mortality, primarily due to the unexpectedly high number of hatchlings and inadequate funds, space and equipment (Ottenwalder, 1994b). Despite these limitations, the programme proved successful, and the seven females in the collection produced 427 hatchlings between February 1992 and July 1994. The programme suffered a steady decline in the second half of 1994 as a result of institutional administrative changes, limiting captive-breeding and head-starting effort, and frustrating the achievement of the re-introduction component as a result of mismanagement, lack of expertise and consequent mortality of hatchlings. None the less, the fact that these turtles can be head-started successfully, reducing substantially the potential risks of predation by herons and land crabs, was demonstrated successfully.

An additional risk to the viability of Trachemys decorata exists if related North American turtles T. scripta are released within the range of the former species. Trachemys scripta has been widely introduced in the West Indies (Seidel, 1996) and has hybridized with other native species. Although not currently a concern in the Dominican Republic, where introduced turtles are not common and none is known from the south-western area of the country, hybridization between these closely related forms would threaten the genetic purity of endemic populations. Precautions should be taken to eliminate the importation of T. scripta for food or for the pet trade.

\section{Trachemys stejnegeri vicina (Emydidae)}

The endemic subspecies of turtle Trachemys stejnegeri vicina is opportunistic and ranges throughout the 'North Paleoisland' (Schwartz, 1980; Schwartz \& Henderson, 1991; Powell et al., 1999). Consequently it is less vulnerable to extinction than $T$. decorata. However, many historical populations have been extirpated and others apparently have declined substantially, even when in protected areas. Incháustegui (1972-73, 1975) published the known information on natural history of the Dominican populations. Habitat destruction, including that of many important wetlands, and pollution are implicated in many instances, but hunting for food continues to take a toll. Because of low numbers, these turtles, like $T$. decorata, are not the focus of efforts at economic exploitation, but ongoing facultative collecting, primarily by local fishermen seeking to supplement meagre incomes by any méans, ensures a continuing decline in most populations. In addition, because of this species's distribution throughout the more heavily populated northern regions of the country, the threat of hybridization with introduced $T$. scripta is greater than for $T$. decorata. Effective conservation efforts must be implemented, and relevant regulations and laws enforced consistently. Population surveys should be supplemented by public education, and captive propagation and release efforts may well be necessary before remaining wild populations can sustain viable levels. For a summary of the pertinent literature, see Seidel (1988). 


\section{Celestus anelpistus (Anguidae)}

The Dominican endemic galliwasp Celestus anelpistus has an extremely localized distribution. It is known only from the type locality (Schwartz \& Henderson, 1991) in broad-leaf lowland forest, a habitat that is nearly gone (Aquino, 1983; Powell et al., 1999). Sugarplantation workers clearing the area from which the type series was taken in 1977 had not previously seen these large lizards (Schwartz et al., 1979), suggesting their rarity, and none has been collected since (Henderson, 1988a). The type locality was cleared totally soon after the original collection and no longer exists as habitat. The only notes on natural history were published with the original description by Schwartz et al. (1979). Although these very large anguid lizards appear to be extremely secretive, maybe even more so than their smaller relatives, they would certainly attract attention when encountered. Consequently, we believe that they are at best exceedingly rare and at worst extinct. Because their habitat is essentially gone and remnants are severely threatened, the necessity for focused surveys is critical and solicitation of protected status of some sort for this species is appropriate and warranted. For a summary of the pertinent literature, see Henderson (1988a).

Two of the specimens on which the formal description was based were gravid females. These individuals gave birth to a total of 42 young between 16 July and 3 August 1977 at ZOODOM. The juveniles were distributed to several zoos (Bronx, Brookfield, Philadelphia, in addition to ZOODOM), but neither the young nor the adults survived more than 3 years.

\section{Celestus carraui (Anguidae)}

Like Celestus anelpistus, the Dominican endemic C. carraui has a restricted distribution; although several localities are known, each probably represents a very small, isolated population. Sites of collection are in xeric and mesic situations at moderate elevations (200-300 m) north and south of the Cordillera Septentrional (Schwartz \& Henderson, 1991). Only a few specimens have been collected in recent years. What little is known about the species's natural history was published with the original description by Incháustegui et al. (1985). Like C. anelpistus, these lizards are very secretive, but because these large and rather spectacular animals would not escape notice if encountered, they are probably rare throughout their range. Efforts to survey areas in which animals have been taken previously and other contiguous areas of suitable habitat should be strongly encouraged. Until more data are available, any decisions regarding the status of this species would be premature. For a summary of the pertinent literature, see Henderson (1988b).

A pair of Celestus carraui, acquired in 1986, gave birth to 12 young in August 1988 at ZOODOM. All died within 3 weeks, although the adults were maintained successfully until 1990. Neonate C. warreni, a similar and relatively more common species endemic to Haiti, have been born at zoos in Knoxville and Milwaukee, but young died soon after birth or did not survive to reproductive age. This history of unsuccessfully breeding giant galliwasps in captivity casts uncertainty on the likelihood of such efforts becoming part of any recovery plan. However, because the risk of extinction of these species appears to be high and natural habitat is diminishing or gone, the removal of either $C$. anelpistus or C. carraui from wild populations to establish captive propagation programmes may be a critical component of any conservation and recovery strategy for either form. In the interim and until wild populations can be surveyed, efforts should be devoted to successfully and consistently breeding in captivity the less critically endangered C. warreni.

\section{Sphaerodactylus cochranae (Gekkonidae)}

The attractive dwarf gecko Sphaerodactylus cochranae is endemic to the karstic Los Haitises region south of the Bahía de Samaná. Prior to its rediscovery in 1997 (Glor, 1999), this species was known from only three individuals, the last of which had been collected in 1973 (Thomas \& Schwartz, 1983). Almost nothing is known of the species's natural history, but recent herpetofaunal surveys in the Los Haitises region (Glor et al., in review) suggest that $S$. cochranae is a bromeliad dweller and exceedingly sensitive to agricultural disturbances. Although a portion of its presumed range is within the boundaries of the Parque Nacional Los Haitises, the entire region has a history of extensive agricultural development and recent (1996-99) surveys indicate that these geckos are absent from agricultural areas. In fact, $S$. cochranae was found only on the park's karstic hilltops (mogotes) that, unlike the surrounding slopes and valleys, were never cleared-and only on these undisturbed mogotes are bromeliads abundant. Apparently, the difficulty of clearing the forested hilltops may be the only reason any populations remain extant. Because $S$. cochranae has a highly restricted distribution, appears to be a habitat specialist, is extremely sensitive to human activities, and may never have been common, its future seems uncertain at best, especially if the mogotes of the region lose their strictly protected status. For a summary of the pertinent literature, see Glor \& Powell (in preparation). 


\section{Cyclura cornuta (Iguanidae)}

The large Hispaniolan endemic iguana Cyclura cornuta has a broad, but fragmented range in xeric areas of the island (Schwartz \& Henderson, 1991; Ottenwalder, 2000a). Formerly very common, nearly all populations have declined (Schwartz \& Henderson, 1991), with substantial declines since even the early 1950s (Ottenwalder, 2000a). These iguanas are maintaining what are assumed to be near pre-Columbian populations densities only in remote or protected areas in Jaragua National Park, at La Azufrada near Lago Enriquillo, and on islas Cabritos and Beata. The La Azufrada population is restricted to a relatively small area $(<5 \mathrm{sq} \mathrm{km})$, but animals of all age groups are present and common. As of 1999, the population on Isla Cabritos appeared to be stable. Frequent visits by tourists to both areas have conditioned iguanas to a non-threatening human presence, resulting in an abundance of sightings. However, both areas are small compared with Jaragua National Park and even to Isla Beata, which in addition to their large size, are accessible only with difficulty, support very low human populations, and afford the iguanas a degree of 'natural' protection. Iguanas also are relatively common in the xeric south-western region from west of Baní past Azua and on into the Valle de Neiba.

Burghardt \& Rand (1982) characterized the species as 'common, but threatened', and noted that populations are faced with accelerating habitat alteration. Ottenwalder (2000a) estimated that relevant habitat loss in the Dominican Republic was about 35 per cent and that, of the remaining original iguana habitat, roughly 75 per cent is disturbed and only about 25 per cent in natural or close to natural conditions. The only major redeeming factor is that preferred habitats are in areas not overly conducive to dense human inhabitation. However, like congeners throughout the West Indies, Cyclura cornuta is sensitive to human activities, vulnerable to predation by the introduced mongoose and feral cats (especially juveniles), susceptible to food resource competition by mammalian herbivores (feral and domestic cattle, burros and goats), and subject to illegal hunting for food and exportation as pets (Schubert, 1993; Ottenwalder, 2000a). Consequently, and in spite of the current status of several protected populations, continued protection under CITES (Appendix I), and national regulations and laws is warranted. In addition, detailed status surveys, especially in areas other than in the south-western part of the country, should be encouraged and introduced-predator eradication programmes should be initiated on Isla Cabritos and on Isla Beata. Cyclura cornuta has been frequently and successfully bred in captivity at more than 20 institutions throughout the world (Bowler, 1996; Ottenwalder, 2000a). The programme at ZOODOM produced an annual average of about 100 young from 1974 to 1994 and included efforts to release captive-bred young in several protected areas in the south-western portion of the country. For a summary of the pertinent literature, see Glor et al. (2000).

\section{Cyclura ricordii (Iguanidae)}

The range of the Dominican endemic iguana Cyclura ricordii is restricted to extremely xeric areas in the Valle de Neiba around Lago Enriquillo and a small area south of the Sierra de Baoruco (Schwartz \& Henderson, 1991). These populations are effectively separated by an extensive ecological barrier composed of the mesic Sierra de Baoruco, with three peaks exceeding $2000 \mathrm{~m}$. In the past, drier Pleistocene climates may have allowed population dispersal and genetic exchange among and between these two populations (Ottenwalder, 2000b). However, such speculation also suggests that the species's range became fragmented and was declining even before the advent of human exploitation and habitat alteration. Although common on Isla Cabritos in Lago Enriquillo, the main island populations are small, and all are 'highly localized' (Burghardt \& Rand, 1982), have declined in historical times, and continue to decline (Ottenwalder, 2000b). Throughout the range, this species is sympatric with $C$. cornuta (which is less of a habitat specialist), and therefore is more vulnerable than C. cornuta to habitat alterations, predation by and competition with exotic species, and illegal hunting. Possibly the best known of sites on the Barahona Peninsula, located inside the fork of the Oviedo-Pedernales and Cabo Rojo-Acetillar bauxite mine roads, has been almost completely destroyed by heavy machinery and habitat conversion to agriculture (Ottenwalder, 2000b). These pressures and the exceedingly limited distribution of the species warrant continued protection under CITES (Appendix I) and national regulations and laws.

A project involving field surveys and ecological studies of the wild populations, one of the top 10 priority conservation projects identified by the IUCN/SSC West Indian Iguana Conservation Action Plan (Alberts, 2000), was initiated and has been ongoing since 1997 at Parque Nacional de Isla Cabritos and the adjacent northern shore of Lago Enriquillo. This study, with participation and support of local institutions and researchers, financial assistance from the Indianapolis Zoological Society, and endorsement of the IUCN/SSC West Indian Iguana Specialists Group (WIISG), is providing material in support of genetic investigations and includes efforts to eradicate feral cats from the island. Additional status surveys, such as those also being conducted by the 
Departamento de Vida Silvestre (DVS) on Isla Cabritos, should be expanded to include all populations. Public education programmes, raising awareness among regional residents, should be developed and implemented. The captive breeding programmes established at the Indianapolis Zoo and ZOODOM (Christie, 1996; Ottenwalder, 2000b) are now inactive because of a lack of animals (none is currently in any US zoo collections; W. Christie, pers. comm.). Because previous captive breeding programmes resulted in low survivorship of young (J. A. Ottenwalder \& W. Christie, unpublished data), successful captive husbandry techniques still need to be developed. Consequently, both breeding programmes should be re-established. Collaborative efforts by both institutions, in co-operation with DVS, are currently in the planning stages. For a summary of the pertinent literature, see Glor et al. (1998).

\section{Alsophis anomalus (Colubridae)}

Only a few specimens of the Hispaniolan endemic snake Alsophis anomalus have been collected in the Dominican Republic, all in widely dispersed xeric areas (Valle de Neiba, Isla Beata and near Monte Cristi) (Schwartz \& Henderson, 1991). Suitable habitats are widespread, but the rarity of specimens combined with the fact that large, diurnally active snakes such as this species are extremely vulnerable to predation by the mongoose (Henderson \& Sajdak, 1986; Henderson, 1992), suggest that extant populations are small and probably declining. This situation is complicated further by the general antipathy exhibited by most Dominicans toward snakes; most people encountering a snake will kill it. Too little information is available to draw any definitive conclusions regarding the status of this species, but efforts to find additional animals and to learn more about the species' natural history should be encouraged. Educational programmes aimed at the general public should emphasize the value of these large, but harmless, predators in rodent control. For a summary of the pertinent literature, see Powell \& Henderson (1998a).

\section{Alsophis melanichnus (Colubridae)}

Only a single specimen of the Hispaniolan endemic snake Alsophis melanichnus is known from the Dominican Republic, an adult male from 'La Vega' (presumably La Vega Province). 'That this species is extant seems very unlikely' (Powell \& Henderson, 1998b). No specimens have been collected since 1910 and the species' rarity in collections suggests that it was never common. Furthermore, like Alsophis anomalus, $A$. melanichnus is extremely vulnerable to predation by the introduced mongoose, which is common throughout the lowlands of Hispaniola. This species should probably be considered extinct (Schubert, 1993). For a summary of the pertinent literature, see Powell \& Henderson (1998b).

\section{laltris agyrtes (Colubridae)}

The endemic snake Ialtris agyrtes is known from only three localities (Schwartz \& Henderson, 1991), all in xeric forests. SEA/DVS (1990) commented on its rarity, which is somewhat surprising because apparently suitable habitat is abundant. Almost nothing is known about these snakes, but their presumably diurnal habits render them, like species of Alsophis, vulnerable to predation by the mongoose. The paucity of data precludes drawing any legitimate conclusions regarding the species' status, except that efforts to find additional individuals and to learn as much as possible about its natural history should be encouraged. For a summary of the pertinent literature, see Powell \& Henderson (1994).

\section{laltris dorsalis (Colubridae)}

The endemic Hispaniolan snake Ialtris dorsalis has a broad, but disjunct distribution across the Dominican Republic (Schwartz \& Henderson, 1991). Although the most commonly encountered of the snakes listed, the paucity of specimens and the facts that most were collected in mesic lowland forest (an extremely vulnerable habitat) and that large, diurnally active snakes are most vulnerable to predation by the mongoose, collectively suggest a species in decline. A general lack of information precludes any definitive conclusions regarding this species' current status, but any efforts to acquire additional information should be encouraged. For a summary of the pertinent literature, see Zippel et al. (1994).

\section{Crocodylus acutus (Crocodylidae)}

Historically widespread throughout Hispaniola, the population of the American crocodile Crocodylus acutus in the Río Yaque del Norte (Montecristi Province) apparently has been extirpated during the last 20 years, leaving the only remaining populations in lakes of the Cul de Sac Plain/Valle de Neiba (Schwartz \& Henderson, 1991). Thorbjarnarson (1988) studied the Haitian population in Etang Saumatre, but its current status is unknown. The Dominican population in Lago Enriquillo has been the focus of many recent conservation efforts (Schubert \& Santana, 1996). Although it was depleted prior and subsequent to the establishment of 
the Isla Cabritos National Park in 1974 (Incháustegui et al., 1978; SEA/DVS, 1993), Schubert \& Santana (1996) suggested that the population has stabilized. However, the length of time necessary for a slowly maturing species to recover, especially in a habitat not known for its high productivity (Incháustegui et al., 1978), suggests that the adult and subadult populations will need considerably more time to recover. Complicating the ability to assess even these recent trends is the fact that animals, in response to extensive human persecution and harassment through the late 1980s, were so frightened by any human presence that they quickly learned to avoid contact by fleeing rapidly, becoming more secretive in their habits, and moving to new areas to avoid humans.

Diligent monitoring, public education, enforcement of applicable regulations and laws, and a captive breeding/head-start programme at ZOODOM have all played important roles in reducing the rate of decline. However, these large animals remain vulnerable to human exploitation because they have potential economic value in a region with limited resources for human development and income generation. Although afforded protection via CITES (Appendix I) and various national efforts, should action in any area lag or the economic circumstances of the local population worsen, this population could easily be extirpated. Consequently, current education and conservation efforts must not be relaxed and existing protective laws and regulations remain essential. For a summary of the pertinent literature, see Ernst et al. (1999).

\section{References}

Alberts, A. (ed.) (2000) West Indian Iguanas. Status Survey and Conservation Action Plan. IUCN-the World Conservation Union, Gland, Switzerland.

Aquino, A.T. (1983) Anfibios y reptiles de la Hispaniola en peligro de extinción. Conferencias, Revista Cientifica de Divulgación, Museo Nacional de Historia Natural, 1, 26-30.

Bickham, J.W. (1980) Chrysemys decorata. Catalogue of American Amphibians and Reptiles, No. 235, 1-2.

Bowler, J.K. (1996) Taxon management account: rhinoceros iguana, Cyclura cornuta cornuta. In American Zoo and Aquarium Association Lizard Advisory Group, Taxon Management Accounts (ed. S. H. Hammack), pp. 1-10. American Zoo and Aquarium Association, Fort Worth, TX

Burghardt, G.M. \& Rand, A.S. (1982) Section IV. Conservation and management. In Iguanas of the World: Their Behavior, Ecology, and Conservation (eds G. M. Burghardt and A. S. Rand), pp. 391-396. Noyes Publishing, Park Ridge, NJ.

Christie, W.D. (1996) Taxon management account: Ricord's iguana, Cyclura ricordi. In American Zoo and Aquarium Association Lizard Advisory Group, Taxon Management
Accounts (ed. S. H. Hammack), pp. 1-7. American Zoo and Aquarium Association, Fort Worth, TX.

Ernst, C.H., Ross, F.D. \& Ross, C.A. (1999) Crocodylus acutus. Catalogue of American Amphibians and Reptiles, No. 700, $1-17$.

Glor, R.E. (1999) Biodiversity assessment for different land uses: rare dwarf gecko rediscovered. In CIIFAD (Cornell International Institute for Food, Agriculture and Development) Annual Report 1997-98, pp. 14-15. Cornell University, Ithaca, NY.

Glor, R.E. \& Powell, R. (in preparation) Sphaerodactylus cochranae. Catalogue of American Amphibians and Reptiles.

Glor, R.E., Powell, R. \& Parmerlee, J.S. Jr. (1998) Cyclura ricordii. Catalogue of American Amphibians and Reptiles, No. 657, 1-3.

Glor, R.E., Powell, R. \& Parmerlee, J.S. Jr. (2000) Cyclura cornuta. Catalogue of American Amphibians and Reptiles, in press.

Glor, R.E., Flecker, A.S., Benard, M.F. \& Power, A.G. (in review) Lizard diversity and agricultural disturbance in a Caribbean forest landscape. Biodiveristy and Conservation.

Green, D.M. (ed.) (1997) Amphibians in Decline: Canadian Studies of a Global Problem. Society for the Study of Amphibians and Reptiles, Herpetological Conservation, No. 1, St. Louis, MO.

Groombridge, B. (ed.) (1993) 1994 IUCN Red List of Threatened Animals. IUCN, Gland, Switzerland.

Harcourt, C. \& Ottenwalder, J. (1996) Hispaniola. In The Conservation Atlas of Tropical Forests, The Americas (eds C. S. Harcourt and J. A. Sayer), pp. 102-111. IUCN, Gland, Switzerland.

Harcourt, C., Billington, C. \& Sayer, J. (1996) Introduction. In The Conservation Atlas of Tropical Forests, The Americas (eds C. S. Harcourt and J. A. Sayer), pp. 9-16. IUCN, Gland, Switzerland.

Hedges, S.B. (1996) Historical biogeography of West Indian vertebrates. Annual Review of Ecology and Systematics, 27, $163-196$.

Hedges, S.B. (1999) Distribution patterns of amphibians in the West Indies. In Regional Patterns of Amphibian Distribution: A Global Perspective (ed. W. E. Duellman), pp. 211-254. Johns Hopkins University Press, Baltimore, MD.

Henderson, R.W. (1988a) Diploglossus anelpistus. Catalogue of American Amphibians and Reptiles, No. 424, 1.

Henderson, R.W. (1988b) Diploglossus carraui. Catalogue of American Amphibians and Reptiles, No. 425, 1.

Henderson, R.W. (1992) Consequences of predator introductions and habitat destruction on amphibians and reptiles in the post-Columbus West Indies. Caribbean Journal of Science, 28, 1-10.

Henderson, R.W. \& Powell, R. (1999) West Indian herpetoecology. In Caribbean Amphibians and Reptiles (ed. B. I. Crother), pp. 223-268. Academic Press, San Diego.

Henderson, R.W. \& Sajdak, R.A. (1986) West Indian racers: a disappearing act or a second chance? Lore, 36, 13-18.

Hoppe, J. (1989) Los Parques Nacionales de la República Dominicana. The National Parks of the Dominican Republic. Editoria Corripio, Santo Domingo.

Incháustegui M., S.J. (1972-73) Las tortugas dominicanas de agua dulce Chrysemys decussata vicina y Chrysemys decorata (Testudinata, Emydidae). Thesis, Licenciatura en Biología, Universidad Autónoma de Santo Domingo, República Dominicana. 
Incháustegui M., S.J. (1975) Las tortugas dominicanas de agua dulce Chrysentys decussata vicina y Chrysemys decorata (Testudinata, Emydidae). Anuario Academia de Ciencias de la República Dominicana, 1, 139-278.

Incháustegui M., S.J., Schwartz, A. \& Henderson, R.W. (1985) Hispaniolan giant Diploglossus (Sauria: Anguidae): description of a new species and notes on the ecology of D. warreni. Amphibia-Reptilia, 6, 195-201.

Incháustegui M., S.J., Gutierrez, W., Rivas, V., Álvarez, V., Nuñez, N. \& Bonnelly, I. (1978) Notas sobre la ecología del Lago Enriquillo. In Conservación y Ecodesarrollo (ed. I. Bonnelly de Calventy), pp. 307-342. Centro de Investigaciones de Biología Marina (CIBIMA), Universidad Autónoma dẹ Santo Domingo (UASD), Colección Ciencia y Tecnología No. 8. Santo Domingo, República Dominicana.

IUCN (International Union for Conservation of Nature and Natural Resources) (1996) 1996 IUCN Red List of Threatened Animals. IUCN, Gland, Switzerland.

Jenkins, M. \& Harcourt, C. (1996) Lesser Antilles. In The Conservation Atlas of Tropical Forests, The Americas (eds C. S. Harcourt and J. A. Sayer), pp. 120-137. IUCN, Gland, Switzerland.

Lenart, L.A., Powell, R., Parmerlee, J.S. Jr., Lathrop, A. \& Smith, D.D. (1997) Anoline diversity in three differentially altered habitats in the Sierra de Baoruco, República Dominicana, Hispaniola. Biotropica, 29, $117-123$.

MacDonald, J.S. (1992) Contemporary size and distribution of population. In The Cambridge Encyclopedia of Latin America and the Caribbean, 2nd edn (eds S. Collier, T. E. Skidmore and H. Blakemore), pp. 151-157. Cambridge University Press, New York.

Ottenwalder, J.A. (1994a) Conservation Program for the South Hispaniolan Slider Turtle (Trachemys decorata) in the Dominican Republic, 1994. Summary Progress Report prepared for the $1994 \mathrm{AZA} / \mathrm{Chelonian}$ Advisory Group Meeting, at the International Herpetological Symposium, New Orleans, June.

Ottenwalder, J.A. (1994b) Translocation and Monitoring Program for the Hispaniolan Slider Turtle (Trachemys decorata). A Proposal for Field Research, Conservation, and Management submitted to the Columbus Zoo's AHSSC Committee.

Ottenwalder, J.A. (2000a) Taxonomic account: Cyclura cornuta cornuta. In West Indian Iguanas: Status Survey and Conservation Action (ed. A. C. Alberts). IUCN-the World Conservation Union, Gland, Switzerland.

Ottenwalder, J.A. (2000b) Taxonomic account: Cyclura ricordi In West Indian Iguanas: Status Survey and Conservation Action (ed. A. C. Alberts). IUCN-the World Conservation Union, Gland, Switzerland.

Ottenwalder, J.A. (2000c) Medio ambiente y sostenibilidad del desarrollo en la República Dominicana. United Nations Development Programme (PNUD), Santo Domingo, República Dominicana, in press.

Powell, R. (1993) Comments on the taxonomic arrangement of some Hispaniolan amphibians and reptiles. Herpetological Review, 24, 135-137.

Powell, R. \& Henderson, R.W. (1994) Ialtris agyrtes. Catalogue of American Amphibians and Reptiles, No. 591, 1-2.
Powell, R. \& Henderson, R.W. (1996) A brief history of West Indian herpetology. In Contributions to West Indian Herpetology: A Tribute to Albert Schwartz (eds R. Powell and R. W. Henderson), pp. 29-50. Society for the Study of Amphibians and Reptiles, Contributions to Herpetology No. 12, Ithaca, NY.

Powell, R. \& Henderson, R.W. (1998a) Alsophis anomalus. Catalogue of American Amphibians and Reptiles, No. 659, $1-2$.

Powell, R. \& Henderson, R.W. (1998b) Alsophis melanichnus. Catalogue of American Amphibians and Reptiles, No. 660, $1-2$.

Powell, R. \& Pregill, G.K. (1991) Peltophryne fluviatica. Catalogue of American Amphibians and Reptiles, No. 507, $1-2$.

Powell, R., Henderson, R.W., Adler, K. \& Dundee, H.A. (1996) An annotated checklist of West Indian amphibians and reptiles. In Contributions to West Indian Herpetology: A Tribute to Albert Schwartz (eds R. Powell and R. W. Henderson), pp. 51-93. Society for the Study of Amphibians and Reptiles, Contributions to Herpetology No. 12, Ithaca, NY.

Powell, R., Ottenwalder, J.A. \& Incháustegui, S.J. (1999) The Hispaniolan herpetofauna: diversity, endemism, and historical perspectives, with comments on Navassa Island. In Caribbean Amphibians and Reptiles (ed. B. I. Crother), pp. 93-168. Academic Press, San Diego.

Pregill, G.K. (1981) Cranial morphology and the evolution of West Indian toads (Salientia: Bufonidae): resurrection of the genus Peltophryne Fitzinger. Copeia, 1981, 273-285.

Schubert, A. (1993) Conservation of biological diversity in the Dominican Republic. Oryx, 27, 115-121.

Schubert, A. \& Santana, G. (1996) Conservation of the American crocodile (Crocodylus acutus) in the Dominican Republic. In Contributions to West Indian Herpetology: A Tribute to Albert Schwartz (eds R. Powell and R. W. Henderson), pp. 425-433. Society for the Study of Amphibians and Reptiles, Contributions to Herpetology No. 12, Ithaca, NY.

Schwartz, A. (1972) The native toads (Anura, Bufonidae) of Hispaniola. Journal of Herpetology, 6, 217-231.

Schwartz, A. (1980) The herpetogeography of Hispaniola, West Indies. Studies of the Fauna of Curaçao and other Caribbean Islands, 61, 86-127.

Schwartz, A. \& Henderson, R.W. (1991) Amphibians and Reptiles of the West Indies: Descriptions, Distributions, and Natural History. University of Florida Press, Gainesville.

Schwartz, A., Graham, E.D. Jr. \& Duval, J.J. (1979) A new species of Diploglossus (Sauria: Anguidae) from Hispaniola. Proceedings of the Biological Society of Washington, 92, 1-9.

SEA/DVS (Secretaría de Estado de Agricultura/Departamento de Vida Silvestre) (1990) La Diversidad Biológica en la República Dominicana: Reporte Preparado por el Departamento de Vida Silvestre para el Servicio Alemán de Cooperación Social-Téchnica y Fondo Mundial para la Naturaleza (WWF-US). Secretaría de Estado de Agricultura, SURENA/DVS, Santo Domingo, República Dominicana.

SEA/DVS (Secretaría de Estado de Agricultura/Departamento de Vida Silvestre) (1993) Estudio y Protección de Cocodrilo Americano (Crocodylus acutus) en la República Dominicana. 
Secretaría de Estado de Agricultura, Departamento de Vida Silvestre, Santo Domingo, República Dominicana.

Seidel, M.E. (1988) Trachemys stejnegeri. Catalogue of American Amphibians and Reptiles, No. 441, 1-3.

Seidel, M.E. (1996) Current status of biogeography of the West Indian turtles in the genus Trachemys (Emydidae). In Contributions to West Indian Herpetology: A Tribute to Albert Schwartz (eds R. Powell and R. W. Henderson), pp. 169-174. Society for the Study of Amphibians and Reptiles, Contributions to Herpetology No. 12, Ithaca, NY.

Thomas, R. \& Schwartz, A. (1983) The difficilis complex of Sphaerodactylus (Sauria, Gekkonidae) of Hispaniola. Part 2. Sphaerodactlylus savagei, S. cochranae, S. darlingtoni, S. armstrongi, S. streptophorus, and conclusions. Bulletin of the Carnegie Museum of Natural History, 22, 31-60.

Thorbjarnarson, J.B. (1988) The status and ecology of the American crocodile in Haiti. Bulletin of the Florida State Museum, Biological Sciences, 33, 1-86.

Tolentino, L. \& Peña, M. (1998) Inventario de la vegetación y uso de la tierra en la República Dominicana. Moscosoa, 10, 179-203.

Valdez Sierra, G. \& Mateo Féliz, J.M. (1992) Sistema de Areas Protegidas de República Dominicana. Fondo Pro-naturaleza, Santo Domingo.

Williams, E.E. (1999) Over 300 years of collecting in the Caribbean. In Caribbean Amphibians and Reptiles (ed. B. I Crother), pp. 1-30. Academic Press, San Diego.

World Resources Institute (1994) World Resources 1994-95.

The World Resources Institute, New York.

Zippel, K.C., Parmerlee, J.S. Jr. \& Powell, R. (1994) Ialtris dorsalis. Catalogue of American Amphibians and Reptiles, No. 592, 1-3.

\section{Biographical sketches}

Sixto J. Incháustegui was Professor of Biology and Coordinator of Zoology at the Autonomous University of Santo Domingo for over 20 years and helped found the National Museum of Natural History. He has been involved in educational and conservation issues at both national and international levels for nearly 35 years. Of particular importance has been his participation in the process of establishing a national protected-areas system. He has served as scientific authority for the Dominican National CITES Committee since the country ratified the Convention, has been the regional representative to CITES's Animals Committee, and Caribbean Vice-chair for IUCN's Commission on Protected Areas. He is one of the founders and former President of the Grupo Jaragua, a national conservation NGO. At present, he is Environmental Officer at the United Nations Development Programme office in the Dominican Republic.

José Ottenwalder co-ordinates the National Environmental Policies Reform Project and the National Biodiversity Strategy and Action Plan of the Dominican Republic. Both are implemented through the Project Co-ordination Unit, which manages World Bank-, UNDP- and GEF-funded projects executed by the National Planning Office. He also co-ordinates a NASA-sponsored pilot project on assessment and monitoring of biodiversity changes in Hispaniola, and recently concluded the Dominican GEF project (Conservation and Management of Coastal Biodiversity). His service with ICBP and SSC/IUCN since 1979 includes past and current regional appointments (steering committee, regional vice-chair and regional member for the Caribbean) and membership in specialist groups for flamingos, insectivores, marine turtles, crocodiles and West Indian iguanas (Deputy Chair). Principal interests include conservation biology and ecology of West Indian/Hispaniolan mammals, birds and reptiles, particularly threatened and endemic species.

Robert Powell is Professor of Biology at Avila College, Kansas City, Missouri. His research, nearly always with undergraduate collaborators, has revolved around the natural history and community ecology of West Indian amphibians and reptiles since 1986, when he made his first visit to the Dominican Republic. He has written over 200 scientific papers, many with undergraduate co-authors. In 1996, he co-edited (with Robert W. Henderson) Contributions to West Indian Herpetology: A Tribute to Albert Schwartz. $\mathrm{He}$ is editor of the Catalogue of American Amphibians and Reptiles and author (with Joseph T. Collins and Errol D. Hooper Jr.) of A Key to Amphibians \& Reptiles of the Continental United States and Canada. 